\title{
EFFECT OF DIFFERENT LEVELS OF SLOW RELEASE FERTILIZERS ON THE PRODUCTION OF LILIUM PLANTS IN DIFFERENT GROWING MEDIA
}

\author{
(Received : 1.12. 2013)
}

\section{By}

\author{
N. A. El-Shanhorey and R. A. Soffar ${ }^{*}$
}

Department of Botanical Garden Research and ${ }^{*}$ Department of Ornamental Plants Research Antoniades, Horticulture Research Institute, Agricultural Research Center,Alexandria,Egypt.

\begin{abstract}
The present study was carried-out during the two successive years of 2010/2011 and 2011/2012 at Antoniades Research Branch, Horticulture Research Institute, A.R.C. Alexandria, Egypt. An experiment was established to test the effect of different levels of slow release fertilizers and different growing media on the production of Lilium hybrida cv. "Golden Tycoon". Four growing media 100\% sand, 75\% sand $+25 \%$ peat, $50 \%$ sand $+50 \%$ peat and $25 \%$ sand $+75 \%$ peat moss were used in combination with 0.0 , 6.0 and $12.0 \mathrm{~g}$ rates of slow release fertilizer (S RF) \{El-Ganem15:15:15 (NPK) \}. Using the high rate of SRF level at $12.0 \mathrm{~g}$ with a media of $50 \%$ sand $+50 \%$ peat moss greatly affected the production of lilium flowering production. Intensively fertilized plants gave higher flower fresh and dry weights, flower diameter, bulb fresh and dry weights, total chlorophylls and carbohydrates and each of NPK content in the leaves and bulbs.
\end{abstract}

Key words: corm production, flower production, growing media, Lilium hybrid cv. "Golden Tycoon", slow release fertilizers, vegetative growth.

\section{INTRODUCTION}

Lilies are very important as cut flowers and pot plants, usually forced year-round. During winter, the most limiting factor in obtaining good flower quality is insufficient light (De Hertogh, 1989; Beattie and White, 1993). However, when the plants are growing during spring and summer months, other factors such as bulb quality after long storage, a high quality, well aerated growing medium and proper fertilization are very important. Lilies are considered to have low to moderate nutrient requirements (Erwin, 1998). It was shown that lilies from different groups (Asiatic or Orientals) have different nutrient requirements (Beattie and White, 1993; Sonneveld et al., 1999). When light conditions during oriental lily forcing were optimal, nutrient uptake increased with increasing fertilization level (Treder, 2001, 2003). It seems that cultivars characterized by a long vegetation period have higher nutrient requirements. Lilies are sensitive to high salinity of the growing medium, especially at the beginning of cultivation. The application of the slow release fertilizer before planting can be a good solution to ensure extended supply of nutrients and prevent high medium salinity. The information about nutrient requirements that affects lilies during cut flower production and about the slow release fertilizer application for this plant is rather limited.

Slow-release fertilizers improve the growth of several plant species. Slow-release fertilizers are safer to handle and labor-saving, compared to conventional NPK fertilizers. However, the price of slow-release fertilizers is higher than other fertilizers. Slow-release fertilizers reduce nitrogen leaching (Volterrani et al.,1999). Also, several researchers have reported that conventional fertilization treatments favorably influence the growth of different climbing and vining plants (Hussein , 2002) on Cryptostegia grandiflora, and Darwish and Sakr, 2008) on Hedera canareinsis).

Different growing media can be used to grow lilium while the physical and chemical properties of media, like structure, texture, $\mathrm{pH}$ as well as nitrogen, phosphorus and potassium are the dominant factors for the growth and development of the plants. Composition and nutritional status of the medium are considered to be helpful for the production of good quality flowering plants with more number of flowers and greater size.

The objectives of this study were to determine 
the influence of fertilization intensity levels of slow-release fertilizer and different growing media on the quality of growth, flowering bulbs production and biochemical composition of Lilium hybrida cv. "Golden tycoon" plants.

\section{MATERIALS AND METHODS}

The present study was carried out during the two successive seasons of 2010/2011 and 2011/2012 at Antoniades Research Branch, Horticulture Research Institute, A.R.E. Alexandria. The aim of the study was to examine the effect of different growing media and different levels of a slow release fertilizer (ElGanem15:15:15 NPK) on the vegetative growth, flowering, bulbs productivity and chemical composition of Lilium hybrida cv. Golden Tycoon.

The plant material was uniform bulbs of Lilium hybrida cultivar namely " Golden Tycoon" with average diameter of $4.1 \mathrm{~cm}$ and $50.0 \mathrm{~g}$ of fresh weight which were obtained from a commercial nursery in Alexandria city. The bulbs were planted on October 11, 2010 and 2011 for the first and the second seasons, respectively, in $30 \mathrm{~cm}$ plastic pots at a depth of $5 \mathrm{~cm}$. after removing all the side bulblets.

Growing media treatments: The media of sand and peat-moss at different ratios were used as follows: $100 \%$ sand, $75 \%$ sand $+25 \%$ peat, $50 \%$ s and $+50 \%$ peat and $25 \%$ sand $+75 \%$ peat used to produce four growing media (Table 1). The chemical analysis of the used media is presented in Table (1).

\section{Data recorded}

(1) Vegetative growth parameters: Plant height $(\mathrm{cm})$, leaf number per plant, leaf area $\left(\mathrm{cm}^{2}\right)$, fresh and dry weights of leaves per plant (g.) .

(2) Flowering growth parameters: the number of days from planting date to showing colour (days), flower diameter $(\mathrm{cm})$, fresh and dry weights of flowers $(\mathrm{g})$, flower stalk diameter $(\mathrm{cm})$, stalk flower fresh and dry weights (g.).

(3) Bulb growth parameters: Bulb diameter $(\mathrm{cm})$, fresh and dry weights of bulbs $(\mathrm{g})$, the number of bulblets per plant .

(4) Chemical analysis determination :

-Total chlorophylls was determined according to Moran and Porath (1980).

-Total carbohydrates of the bulbs was determined according to Dubios et al.(1956).

-Nitrogen, phosphorus and potassium in the leaves and bulbs were determined according to the methods described by Allen (1959), Jackson (1962) and Champman and Pratt (1961), respectively.

The experimental design was a split plot design with three replicates. Each replicate contained 12 different treatments and three plants were used as an experimental unit (plot) for each treatment. The main plot represented the different medium, while the subplot represented the fertilization levels. The means of the individual factors and their interactions were compared by L.S.D test at $5 \%$ level of probability according to Snedecor and Cochran (1974).

Table (1): Chemical analysis of the different growing media for the first season (2010).

\begin{tabular}{|c|c|c|c|c|c|c|c|c|c|}
\hline \multirow{2}{*}{ Growing medium } & \multirow{2}{*}{ pH } & \multirow{2}{*}{$\begin{array}{c}E C \\
\left(\mathrm{dSm}^{-1}\right)\end{array}$} & \multicolumn{4}{|c|}{ Soluble cations (mg/l) } & \multicolumn{3}{|c|}{ Soluble anions (mg/l) } \\
\hline & & & $\mathrm{Ca}^{++}$ & $\mathbf{M g}^{++}$ & $\mathrm{Na}^{+}$ & $\overline{\mathbf{K}^{+}}$ & $\mathrm{HCO}_{3}{ }^{-}$ & $\mathrm{Cl}^{-}$ & $\mathrm{SO}_{2}^{--}$ \\
\hline Sand $(100 \%)$ & 7.7 & 0.45 & 0.38 & 0.12 & 0.70 & 0.02 & 0.31 & 0.19 & 0.72 \\
\hline Sand+Peat $(75 \%+25 \%)$ & 7.5 & 0.68 & 1.04 & 0.20 & 1.19 & 0.14 & 0.33 & 0.59 & 1.22 \\
\hline Sand+Peat $(50 \%+50 \%)$ & 7.3 & 0.93 & 1.82 & 0.31 & 1.76 & 0.23 & 0.35 & 1.06 & 2.51 \\
\hline Sand+Peat $(25 \%+75 \%)$ & 7.1 & 1.15 & 2.31 & 0.45 & 1.94 & 0.31 & 0.38 & 1.35 & 3.20 \\
\hline
\end{tabular}

Fertilizer treatments: A slow complete release fertilizer of El-Ganem $15 \mathrm{~N}: 15 \mathrm{P}: 15 \mathrm{~K}$ was used once at zero, 6 and $12 \mathrm{~g} /$ pot before culture. The fertilizer levels were added to the different growing media with all possible combinations to produce 12 treatments ( 3 fertilizer levels $* 4$ growing media).

\section{RESULTS \\ 3.1.Vegetative growth characteristics 3.1.1.Plant height $(\mathrm{cm})$}

Data in Table (2) showed a significant difference in the plant height at the harvest time. Growing plants in the mixture of $50 \%$ sand $+50 \%$ peat moss in a combination of $12.00 \mathrm{~g}$ of SRF 
Table (2): Means of vegetative growth characteristics of Lilium hybrida cv. Golden Tycoon plants using different growing media (DGM), slow release fertilizer (SRF) and their combinations (DGM $\times$ SRF) in the two seasons of 2010 and 2011.

\begin{tabular}{|c|c|c|c|c|c|c|c|c|c|c|c|}
\hline \multirow[t]{2}{*}{ Media } & \multirow[t]{2}{*}{$\begin{array}{c}\text { SRF } \\
\text { Fertilizers }\end{array}$} & \multicolumn{2}{|c|}{$\begin{array}{l}\text { Plant height } \\
\text { (cm) }\end{array}$} & \multicolumn{2}{|c|}{$\begin{array}{c}\text { Number of } \\
\text { leaves per } \\
\text { plant }\end{array}$} & \multicolumn{2}{|c|}{$\begin{array}{l}\text { Leaf fresh } \\
\text { weight per } \\
\text { plant (g) }\end{array}$} & \multicolumn{2}{|c|}{$\begin{array}{l}\text { Leaf dry } \\
\text { weight per } \\
\text { plant (g) }\end{array}$} & \multicolumn{2}{|c|}{$\begin{array}{c}\text { Leaf area }\left(\mathrm{cm}^{2} /\right. \\
\text { plant })\end{array}$} \\
\hline & & 2010 & 2011 & 2010 & 2011 & 2010 & 2011 & 2010 & 2011 & 2010 & 2011 \\
\hline \multirow[t]{3}{*}{ Send100\% } & Fertilizer 0g & 66.83 & 69.83 & 71.66 & 75.83 & 17.51 & 20.43 & 3.43 & 4.00 & 286.53 & 303.12 \\
\hline & Fertilizer $6 \mathrm{~g}$ & 67.16 & 70.33 & 72.16 & 75.83 & 17.75 & 20.53 & 3.48 & 4.02 & 300.58 & 316.16 \\
\hline & Fertilizer $12 \mathrm{~g}$ & 67.33 & 70.50 & 72.16 & 76.00 & 17.80 & 20.58 & 3.50 & 4.02 & 312.62 & 329.24 \\
\hline Mean & & 67.10 & 70.22 & 71.99 & 75.88 & 17.68 & 20.51 & 3.47 & 4.01 & 299.91 & 316.17 \\
\hline \multirow{4}{*}{$\begin{array}{r}\text { Send } 75 \% \\
+ \text { peat } \\
\text { moss } 25 \%\end{array}$} & Fertilizer 0g & 72.50 & 75.66 & 77.66 & 81.50 & 19.28 & 22.23 & 3.77 & 4.35 & 462.66 & 485.66 \\
\hline & Fertilizer $6 \mathrm{~g}$ & 81.83 & 85.00 & 87.00 & 91.00 & 21.95 & 25.21 & 4.30 & 4.95 & 587.43 & 614.56 \\
\hline & Fertilizer $12 \mathrm{~g}$ & 84.00 & 86.66 & 89.00 & 93.50 & 22.48 & 25.79 & 4.41 & 5.05 & 553.16 & 581.06 \\
\hline & & 79.44 & 82.44 & 84.55 & 88.66 & 21.23 & 24.41 & 4.16 & 4.78 & 534.41 & 560.42 \\
\hline \multirow{4}{*}{$\begin{array}{l}\text { Send } 50 \\
\% \\
\text { + peat } \\
\text { moss } 50 \%\end{array}$} & Fert & 74.16 & 77.50 & 79.33 & 84.16 & 19.79 & 22.81 & 3.88 & 4.46 & 674.75 & 716.00 \\
\hline & Fertilizer 6g & 81.33 & 84.50 & 86.50 & 90.16 & 21.78 & 25.05 & 4.27 & 4.88 & 908.08 & 946.83 \\
\hline & Fertilizer $12 \mathrm{~g}$ & 87.50 & 90.33 & 92.33 & 95.66 & 23.48 & 26.90 & 4.59 & 5.28 & 939.08 & 972.33 \\
\hline & & 80.99 & 84.11 & 86.05 & 89.99 & 21.68 & 24.92 & 4.24 & 4.87 & 840.63 & 878.38 \\
\hline \multirow{3}{*}{$\begin{array}{r}\text { Send } 25 \% \\
+ \text { peat } \\
\text { moss } 75 \%\end{array}$} & Fertilizer $0 \mathrm{~g}$ & 72.50 & 75.33 & 77.33 & 81.83 & 19.20 & 22.13 & 3.76 & 4.32 & 570.05 & 601.62 \\
\hline & Fertilizer $6 \mathrm{~g}$ & 76.50 & 79.33 & 81.33 & 84.83 & 20.34 & 23.40 & 3.97 & 4.58 & 688.81 & 716.81 \\
\hline & Fertilizer $12 \mathrm{~g}$ & 83.16 & 86.33 & 88.00 & 92.00 & 22.28 & 25.56 & 4.36 & 5.00 & 648.87 & 678.37 \\
\hline Mean & & 77.38 & 80.33 & 82.22 & 86.22 & 20.60 & 23.69 & 4.03 & 4.63 & 635.91 & 665.60 \\
\hline \multirow{3}{*}{$\begin{array}{l}\text { Mean } \\
\text { (SRF) }\end{array}$} & Fertilizer $0 \mathrm{~g}$ & 71.49 & 74.58 & 76.49 & 80.83 & 18.94 & 21.90 & 3.71 & 4.28 & 498.49 & 526.60 \\
\hline & Fertilizer $6 \mathrm{~g}$ & 76.70 & 79.79 & 81.74 & 85.45 & 20.45 & 23.54 & 4.00 & 4.60 & 621.22 & 648.59 \\
\hline & Fertilizer $12 \mathrm{~g}$ & 80.49 & 83.45 & 85.37 & 89.29 & 21.51 & 24.70 & 4.21 & 4.83 & 613.43 & 640.25 \\
\hline \multirow{3}{*}{$\begin{array}{l}\text { L.SD.at } \\
0.05\end{array}$} & DGM & 1.56 & 1.47 & 1.56 & 1.76 & 0.38 & 0.45 & 0.07 & 0.09 & 55.60 & 56.10 \\
\hline & SRF & 1.03 & 1.03 & 0.98 & 0.98 & 0.30 & 0.33 & 0.06 & 0.06 & 17.80 & 21.27 \\
\hline & DGMXSRF & 2.30 & 2.24 & 2.24 & 2.38 & 0.62 & 0.71 & 0.12 & 0.15 & 62.63 & 65.85 \\
\hline
\end{tabular}


gave the tallest plant height 87.50 and $90.33 \mathrm{~cm}$ in the first and second seasons, respectively. While, the shortest plants were found with the treatment of $100 \%$ sand at all SRF levels which were $66.83,67.16,67.33 \mathrm{~cm}$ and $69.83,70.33$ and $70.50 \mathrm{~cm}$ in both seasons, respectively.

\subsubsection{Number of leaves per plant}

Data in Table (2) obviously indicated the superiority of using medium of $(50 \%$ of peatmoss $+50 \%$ sand) treatment in the combination of the highest SRF (12.0g) on the number of leaves gave 92.33 and 95.66 leaves per plant in the two seasons, respectively. While using $100 \%$ sand with any SRF treatments $(0,6.0$ and $12.0 \mathrm{~g} / \mathrm{plant}$ ) gave the lowest number of leaves in the first season (71.66, 72.16 and 72.16 leaves per plant), (75.83, 75.83 and 76.0 leaves per plant) in the second one, respectively.

\subsubsection{Leaves fresh weight per plant $(\mathrm{g})$}

The obtained data in Table (2) showed that SRF at maximum level (12.0 g pot) in combination with the treatment of $(50 \%$ sand + $50 \%$ peat moss) produced the heaviest, the best leaf fresh weight of leaves (23.49 and $26.91 \mathrm{~g})$ in both seasons, respectively. While using $(100 \%$ sand) media with all SRF levels gave the least leaf fresh weight $(17.51,17.75$ and $17.80 \mathrm{~g})$ in 2010 season and $(20.43,20.53$ and $20.58 \mathrm{~g})$ in the second season 2011.

\subsubsection{Leaf dry weight per plant (g)}

The data presented (Table 2) showed that increasing the SRF level to $12.0 \mathrm{~g}$ for plants growing in $50 \%$ sand $+50 \%$ peat moss gave the highest leaf dry weight (4.59 and $5.28 \mathrm{~g}$ ) per plant. While the least leaf dry weight was produced using (100\% sand) medium treatment with the combination of any of the SRF levels which were $(3.43,3.48$ and $3.50 \mathrm{~g}$ per plant) in 2010 and (4.00, 4.02 and $4.02 \mathrm{~g}$ per plant) in the second season.

\subsubsection{Leaf area $\left(\mathrm{cm}^{2} /\right.$ plant $)$}

The data in Table (2) indicated that there were significant differences between the highest and lowest rates of SRF. Using SRF at the rates of 6.0 and $12.0 \mathrm{~g}$ with a combination of the media medium of (50\% sand $+50 \%$ peat moss) gave the highest leaf area (908.08 and 939.08 $\mathrm{cm}^{2}$ ) per plant in the first season and $(946.83$ and $972.33 \mathrm{~cm}^{2}$ ) in the second season,.

While the least leaf area was produced using the $100 \%$ sand medium with all SRF levels which gave the least leaf area (286.53, 300.58 and $312.62 \mathrm{~cm}^{2}$ per plant) in 2010 season and (303.12, 316.16 and $329.24 \mathrm{~cm}^{2}$ per plant) in 2011season.

\subsection{Flowering characteristics}

\subsubsection{Number of days to showing colour (days)}

The data in Table (3) indicated that the earlier shown colour in the first season was obtained with the treatment of $6.0 \mathrm{~g} \mathrm{SRF}$ in combination with (25\% sand $+75 \%$ peat moss). This was 84.83 days in the first season and 83.33 days in the second one. The highest number of days to showing colour was recorded with the treatment of $0.0 \mathrm{~g} \mathrm{SRF}$ and $100 \%$ sand medium, 93.33 and 91.66 days, in the two seasons, respectively.

\subsubsection{Flower diameter $(\mathbf{c m})$}

All plants in this study gave five flowers per stalk and the flower diameter represents the average of the five flowers. Using fertilization at the two levels of 6.0 and $12.0 \mathrm{~g}$ in combination of the medium of (50\% sand $+50 \%$ peat moss) gave the highest flower diameter 18.83 and $18.91 \mathrm{~cm}$ in the first season and 19.16 and $19.08 \mathrm{~cm}$ in the second one. Whereas, the control plants grown in $100 \%$ sand produced the lowest flower diameter 15.91 and $16.08 \mathrm{~cm}$ in both seasons, respectively, (Table 3).

\subsubsection{Flower fresh weight $(\mathrm{g})$}

Growing Lilium hybrida cv " Golden Tycoon" in the medium of $50 \%$ sand $+50 \%$ peat moss in combination with the highest SRF at 12.0 g gave the highest flower fresh weight (19.57 and $22.47 \mathrm{~g}$ ) in the two seasons 2010/2011 and 2011/2012, respectively.

However, increasing the SRF levels in combination with a medium of $100 \%$ sand gave the least FW (14.81and 14.81g) in 2010/2011 season and (17.12 and 17.15 g) in 2011/2012 season as shown in Table (3).

\subsubsection{Flower dry weight (g)}

The same trend of results was found in the flower dry weight. Whereas, the interaction between the growing medium of $(50 \%$ sand + $50 \%$ peat moss) and the highest rate of fertilizer in $12.0 \mathrm{~g}$ gave the heaviest dry weight at the two seasons, respectively (4.59 and $5.28 \mathrm{~g}$ ). All SRF levels with a medium $100 \%$ sand gave the lowest FDW at the two seasons, giving, 3.54, 3.60 and $3.60 \mathrm{~g}$ at $2010 / 2011$ and $4.14,4.17$ and $4.17 \mathrm{~g}$ at 2011/2012 respectively, as shown in Table (3).

\subsubsection{Flower stalk diameter $(\mathrm{cm})$}

The data represented in Table (3), showed that the fertilization at the rate of $6.0 \mathrm{~g}$ per plant, for plants grown in $(25 \%$ sand $+75 \%$ peat moss), gave the highest stalk diameter, 0.92 and $0.94 \mathrm{~cm}$ at the two seasons, respectively. While 
Table (3): Means of flowering characteristics of Lilium hybrida cv. Golden Tycoon plants as influenced by different growing media (DGM), slow release fertilizer (SRF) and their combinations (DGM $\times$ SRF) in the two seasons of 2010 and 2011.

\begin{tabular}{|c|c|c|c|c|c|c|c|c|c|c|c|c|c|c|c|}
\hline \multirow[t]{2}{*}{ Media } & \multirow[t]{2}{*}{$\begin{array}{c}\text { SRF } \\
\text { Fertiizers }\end{array}$} & \multicolumn{2}{|c|}{$\begin{array}{l}\text { Number of } \\
\text { days to } \\
\text { showing } \\
\text { colour (day) }\end{array}$} & \multicolumn{2}{|c|}{$\begin{array}{c}\text { Flower } \\
\text { diameter }(\mathrm{cm})\end{array}$} & \multicolumn{2}{|c|}{$\begin{array}{c}\text { Flower fresh } \\
\text { weight (g) }\end{array}$} & \multicolumn{2}{|c|}{$\begin{array}{l}\text { Flower dry } \\
\text { weight (g) }\end{array}$} & \multicolumn{2}{|c|}{$\begin{array}{c}\text { Flower } \\
\text { stalk } \\
\text { diameter } \\
(\mathbf{c m})\end{array}$} & \multicolumn{2}{|c|}{$\begin{array}{l}\text { Flowering } \\
\text { stalk fresh } \\
\text { weight (g) }\end{array}$} & \multicolumn{2}{|c|}{$\begin{array}{l}\text { Flowering } \\
\text { stalk dry } \\
\text { weight (g) }\end{array}$} \\
\hline & & 2010 & 2011 & 2010 & 2011 & 2010 & 2011 & 2010 & 2011 & 2010 & 2011 & 2010 & 2011 & 2010 & 2011 \\
\hline \multirow{3}{*}{$\begin{array}{l}\text { Sand } \\
100 \%\end{array}$} & $\begin{array}{l}\text { Fertilizer } \\
0 \mathrm{~g}\end{array}$ & 93.33 & 91.66 & 15.91 & 16.08 & 14.61 & 17.02 & 3.43 & 4.00 & 0.76 & 0.77 & 10.60 & 11.08 & 1.07 & 1.09 \\
\hline & $\begin{array}{l}\text { Fertilizer } \\
6 \mathrm{~g}\end{array}$ & 90.16 & 88.66 & 16.83 & 17.08 & 14.80 & 17.12 & 3.48 & 4.02 & 0.86 & 0.87 & 10.74 & 11.25 & 1.06 & 1.12 \\
\hline & $\begin{array}{l}\text { Fertilizer } \\
12 \mathrm{~g}\end{array}$ & 87.66 & 86.00 & 16.75 & 16.91 & 14.81 & 17.15 & 3.50 & 4.02 & 0.88 & 0.89 & 10.78 & 11.30 & 1.07 & 1.11 \\
\hline \multicolumn{2}{|l|}{ Mean } & 90.38 & 88.77 & 16.49 & 16.69 & 14.74 & 17.09 & 3.47 & 4.01 & 0.83 & 0.84 & 10.70 & 11.21 & 1.06 & 1.10 \\
\hline \multirow{3}{*}{$\begin{array}{l}\text { Sand } \\
75 \%+\text { Peat } \\
\text { moss } 25 \%\end{array}$} & $\begin{array}{l}\text { Fertilizer } \\
0 \mathrm{~g}\end{array}$ & 90.33 & 88.66 & 17.50 & 17.50 & 16.08 & 18.51 & 3.77 & 4.35 & 0.84 & 0.85 & 11.61 & 12.21 & 1.14 & 1.21 \\
\hline & $\begin{array}{l}\text { Fertilizer } \\
6 \mathrm{~g}\end{array}$ & 91.16 & 89.33 & 17.91 & 18.08 & 18.32 & 21.01 & 4.30 & 4.95 & 0.88 & 0.88 & 13.09 & 13.56 & 1.29 & 1.34 \\
\hline & $\begin{array}{l}\text { Fertilizer } \\
12 \mathrm{~g}\end{array}$ & 88.66 & 87.00 & 16.91 & 17.08 & 18.75 & 21.49 & 4.41 & 5.05 & 0.89 & 0.90 & 13.36 & 13.85 & 1.33 & 1.37 \\
\hline \multicolumn{2}{|l|}{ Mean } & 90.05 & 88.33 & 17.44 & 17.55 & 17.71 & 20.33 & 4.16 & 4.78 & 0.87 & 0.87 & 12.68 & 13.20 & 1.25 & 1.30 \\
\hline \multirow{3}{*}{$\begin{array}{l}\text { Sand } \\
50 \%+\text { Peat } \\
\text { moss } 50 \%\end{array}$} & $\begin{array}{l}\text { Fertilizer } \\
0 \mathrm{~g}\end{array}$ & 92.16 & 89.66 & 17.91 & 18.08 & 16.50 & 18.99 & 3.88 & 4.46 & 0.78 & 0.80 & 11.84 & 12.36 & 1.18 & 1.22 \\
\hline & $\begin{array}{l}\text { Fertilizer } \\
6 \mathrm{~g}\end{array}$ & 86.33 & 85.00 & 18.83 & 19.16 & 18.19 & 20.85 & 4.27 & 4.88 & 0.90 & 0.92 & 13.02 & 13.49 & 1.28 & 1.33 \\
\hline & $\begin{array}{l}\text { Fertilizer } \\
12 \mathrm{~g}\end{array}$ & 89.33 & 87.33 & 18.91 & 19.08 & 19.57 & 22.47 & 4.59 & 5.28 & 0.81 & 0.83 & 13.94 & 14.41 & 1.37 & 1.42 \\
\hline \multicolumn{2}{|l|}{ Mean } & 89.27 & 87.33 & $\mathbf{1 8 . 5 5}$ & 18.77 & 18.08 & 20.77 & 4.24 & 4.87 & 0.83 & 0.85 & 12.93 & 13.42 & 1.27 & 1.32 \\
\hline \multirow{3}{*}{$\begin{array}{l}\text { Sand } \\
25 \%+\text { Peat } \\
\text { moss } 75 \%\end{array}$} & $\begin{array}{l}\text { Fertilizer } \\
0 \mathrm{~g}\end{array}$ & 90.00 & 88.33 & 17.75 & 18.00 & 15.97 & 18.42 & 3.76 & 4.32 & 0.84 & 0.86 & 11.52 & 12.01 & 1.15 & 1.21 \\
\hline & $\begin{array}{l}\text { Fertilizer } \\
6 \mathrm{~g}\end{array}$ & 84.83 & 83.33 & 18.50 & 18.50 & 16.93 & 19.52 & 3.97 & 4.58 & 0.92 & 0.94 & 12.18 & 12.63 & 1.21 & 1.25 \\
\hline & $\begin{array}{l}\text { Fertilizer } \\
12 \mathrm{~g}\end{array}$ & 87.00 & 84.16 & 17.83 & 18.08 & 18.50 & 21.29 & 4.36 & 5.00 & 0.89 & 0.90 & 13.25 & 13.72 & 1.31 & 1.35 \\
\hline \multicolumn{2}{|l|}{ Mean } & 87.27 & 85.27 & 18.02 & 18.19 & 17.13 & 19.74 & 4.03 & 4.63 & 0.88 & 0.90 & 12.31 & 12.78 & 1.22 & 1.27 \\
\hline \multirow{3}{*}{$\begin{array}{l}\text { Mean } \\
\text { (SRF) }\end{array}$} & $\begin{array}{l}\text { Fertilizer } \\
0 \mathrm{~g}\end{array}$ & 91.45 & 89.57 & 17.26 & 17.41 & 15.79 & 18.23 & 3.71 & 4.28 & 0.80 & 0.82 & 11.39 & 11.91 & 1.13 & 1.182 \\
\hline & $\begin{array}{l}\text { Fertilizer } \\
6 \mathrm{~g}\end{array}$ & 88.12 & 86.58 & 18.01 & 18.20 & 17.06 & 19.62 & 4.00 & 4.60 & 0.89 & 0.90 & 12.25 & 12.73 & 1.21 & 1.26 \\
\hline & $\begin{array}{l}\text { Fertilizer } \\
12 \mathrm{~g}\end{array}$ & 88.16 & 86.12 & 17.60 & 17.78 & 17.90 & 20.60 & 4.21 & 4.83 & 0.86 & 0.88 & 12.83 & 13.32 & 1.27 & 1.31 \\
\hline \multirow{3}{*}{$\begin{array}{l}\text { L.S.D. at } \\
0.05\end{array}$} & DGM & $\mathbf{0 . 3 0}$ & 0.39 & 0.09 & 0.09 & $\mathbf{0 . 3 5}$ & 0.44 & 0.16 & 0.12 & 0.01 & 0.01 & 0.19 & 0.18 & $\mathbf{0 . 0 3}$ & 0.01 \\
\hline & SRF & 0.26 & 0.28 & 0.06 & 0.06 & 0.26 & $\begin{array}{l}\mathbf{0 . 3 1} \\
\end{array}$ & 0.15 & 0.27 & 0.01 & 0.01 & $\begin{array}{l}0.17 \\
\end{array}$ & 0.16 & 0.02 & 0.01 \\
\hline & $\begin{array}{l}\text { DGM } \times \\
\text { SRF }\end{array}$ & 0.55 & 0.68 & 0.29 & 0.46 & 0.52 & 0.61 & 0.14 & 0.15 & $\mathbf{0 . 0 2}$ & $\mathbf{0 . 0 2}$ & 0.35 & 0.29 & 0.14 & 0.03 \\
\hline
\end{tabular}


the lowest stalk diameter was produced, when plants were grown in sand alone $(0.76$ and 0.77 $\mathrm{cm}$ ), without SRF, in the two seasons, respectively.

\subsubsection{Flowering stalk fresh weight (g)}

The data in Table (3) showed that using the high rate of SRF fertilization $(12.0 \mathrm{~g})$ in a combination with a medium of $50 \%$ sand $+50 \%$ peat moss gave the heaviest flowering stalk fresh weight 13.94 and $14.41 \mathrm{~g}$ in the two seasons, respectively. However, growing lilium in 100\% sand medium and fertilized with all SRF levels gave the lowest flowering stalk fresh weights $10.60,10.74$ and $10.18 \mathrm{~g}$ in the first season and $11.08,11.25$ and $11.30 \mathrm{~g}$ in the second season.

\subsubsection{Flowering stalk dry weight (g)}

The same trend of fresh weight in response to the different treatments was obtained in the flowering stalk dry weight. Using a medium of $(50 \%$ sand $+50 \%$ peat moss) with the high rate of SRF $12.0 \mathrm{~g}$ gave the heaviest flowering stalk dry weight in $(1.37$ and $1.42 \mathrm{~g})$ in the two seasons, respectively. The lowest flowering stalk dry weight in 2010 season was obtained using $6.0 \mathrm{~g}$ treatment of SRF and media of $100 \%$ sand treatment $1.06 \mathrm{~g}$. However, in the second season the lowest flowering stalk dry weight was noted using $100 \%$ sand treatment in a combination with all SRF rates $1.09,1.12$ and $1.11 \mathrm{~g}$.

\subsection{Bulbs productions (bulbs and bulblets)}

Bulb productions are considered with bulb diameter, bulb fresh and dry weights and the number of bulblets per bulb.

\subsubsection{Bulb diameter $(\mathbf{c m})$}

The data recorded in Table (4) showed that increasing the fertilization rate at $12.0 \mathrm{~g}$ per plant of SRF with using a medium of $(25 \%$ sand $+75 \%$ peat moss) gave the largest bulb diameter 4.84 and $5.25 \mathrm{~cm}$ in the two seasons, respectively. Whereas, it was recorded that decreasing the fertilization at the rate of $0.0 \mathrm{~g}$ SRF in combination with a medium of $100 \%$ sand significantly decreased the bulb diameter ( 3.61 and $4.01 \mathrm{~cm})$ as compared with other combinations in the two seasons, respectively.

\subsubsection{Bulb fresh weight $(\mathrm{g})$}

Growing the bulbs in a medium of $(50 \%$ sand + $50 \%$ peat moss) and using the high rate of $12.0 \mathrm{~g}$ SRF gave the highest bulb fresh weight 41.52 and $43.01 \mathrm{~g}$ at the seasons of 2010/2011 and 2011/2012. However, the plants receiving all SRF rates in the medium of $100 \%$ sand gave the lowest bulb fresh weights in the first season $31.59,31.97$ and $32.05 \mathrm{~g}$ and $33.10,33.48$ and $33.56 \mathrm{~g}$ in the second season resulted from 0.0,6.0 and 12.0 $\mathrm{g} /$ plant, respectively.

\subsubsection{Bulb dry weight (g)}

Increasing the SRF at the rate of $12.0 \mathrm{~g}$ in combination with a medium of $(50 \%$ sand $+50 \%$ peat moss) treatment gave the highest bulb dry weight of 8.63 and $8.93 \mathrm{~g}$ in 2010 and 2011 seasons, respectively. The lowest bulb dry weight was obtained using $100 \%$ sand treatment in combination with all SRF rates which were 6.56 , 6.64 and $6.66 \mathrm{~g}$ bulb in the first season and 6.87, 6.96 and $6.97 \mathrm{~g}$ at the second one.

\subsubsection{Number of bulblets per plant}

The interaction between the two experimental factors in the number of bulbelts per plant was not significant. The data showed that plants grown in $(25 \%$ sand $+75 \%$ peat moss $)$ and $(50 \%$ sand + $50 \%$ peat moss) formed the highest number of bulblets per bulb which were 3.38 and 3.33 in 2010/2011 and the lowest one was 2.61 for plants grown in sand medium. Whereas, in the second season growing mixture $(25 \%$ sand $+75 \%$ peat moss) gave the highest number of bulblets per bulb (3.48), while the lowest one was 2.70 which obtained with $100 \%$ sand medium. On the other hand, increasing the rate of fertilization caused an increase in the number of bulblets per bulb. The highest number was 3.24 using $12.0 \mathrm{~g}$ of SRF while the lowest was 2.86 using $0.0 \mathrm{~g}$ SRF in the first season. The same trend of results was observed in the second season where the highest number of bulblets per bulb was recorded using 12.0 g SRF (3.33) and the lowest one was 2.96 bulblets using $100 \%$ sand medium.

\subsection{Chemical analysis}

\subsubsection{Total chlorophyll content in leaves $(\mathrm{mg} / \mathrm{g}$ F.W.)}

The results presented in Table (5) showed that the highest value of total chlorophyll content in the leaves was produced by using $6.0 \mathrm{~g}$ of SRF treatment and media of $(50 \%$ sand $+50 \%$ peat moss) mixture medium treatment 1.316 and 1.32 $\mathrm{mg} / 100 \mathrm{~g}$ in the two seasons. The lowest total chlorophyll content was a result of $0.0 \mathrm{~g}$ SRF and $75 \%$ sand $+25 \%$ peat moss medium( 0.918 and $0.922 \mathrm{mg} / \mathrm{g}$ ) in the two seasons, respectively.

\subsubsection{Total carbohydrate content in bulbs $(\%)$}

The data presented in Table (5) showed that increasing fertilization up to $12.0 \mathrm{~g}$ SRF in combination of the two media (50\% sand $+50 \%$ peat moss) and $25 \%$ sand $+75 \%$ peat moss gave a significant increase in the total carbohydrate content in bulb (39.27 and 39.27\%) in 2010/2011 season. The lowest total carbohydrate content in 
Table (4): Mean of bulb production of Lilium hybrida cv. Golden Tycoon plants as influenced by different growing media (DGM), slow release fertilizer (SRF) and their combinations $(\mathrm{DGM} \times \mathrm{SRF})$ in the two seasons of 2010 and 2011.

\begin{tabular}{|c|c|c|c|c|c|c|c|c|c|}
\hline \multirow[t]{2}{*}{ Media } & \multirow[t]{2}{*}{ SRF fertilzers } & \multicolumn{2}{|c|}{$\begin{array}{c}\text { Bulb } \\
\text { diameter } \\
(\mathrm{cm})\end{array}$} & \multicolumn{2}{|c|}{$\begin{array}{l}\text { Bulb fresh } \\
\text { weight (g) }\end{array}$} & \multicolumn{2}{|c|}{$\begin{array}{l}\text { Bulb dry } \\
\text { weight (g) }\end{array}$} & \multicolumn{2}{|c|}{$\begin{array}{c}\text { Number of } \\
\text { bulblets per } \\
\text { plant }\end{array}$} \\
\hline & & 2010 & 2011 & 2010 & 2011 & 2010 & 2011 & 2010 & 2011 \\
\hline \multirow{3}{*}{ Sand $100 \%$} & Fertilizer $0 \mathrm{~g}$ & 3.61 & 4.01 & 31.59 & 33.10 & 6.56 & 6.87 & 5.66 & 6.16 \\
\hline & Fertilizer $6 \mathrm{~g}$ & 3.80 & 4.16 & 31.97 & 33.48 & 6.64 & 6.96 & 7.50 & 8.00 \\
\hline & Fertilizer $12 \mathrm{~g}$ & 4.01 & 4.34 & 32.05 & 33.56 & 6.66 & 6.97 & 7.33 & 7.83 \\
\hline \multicolumn{2}{|l|}{ Mean } & 3.80 & 4.17 & 31.87 & 33.38 & 6.62 & 6.93 & 6.83 & 7.33 \\
\hline \multirow{3}{*}{$\begin{array}{l}\text { Sand } 75 \%+\text { Peat moss } \\
25 \%\end{array}$} & Fertilizer $0 \mathrm{~g}$ & 3.97 & 4.34 & 34.51 & 36.02 & 7.17 & 7.48 & 8.00 & 8.50 \\
\hline & Fertilizer $6 \mathrm{~g}$ & 4.03 & 4.40 & 38.97 & 40.48 & 8.09 & 8.41 & 9.66 & 10.16 \\
\hline & Fertilizer $12 \mathrm{~g}$ & 4.45 & 4.77 & 39.86 & 41.35 & 8.29 & 8.61 & 9.16 & 9.83 \\
\hline \multicolumn{2}{|l|}{ Mean } & 4.15 & 4.50 & 37.78 & 39.28 & 7.85 & 8.16 & 8.94 & 9.49 \\
\hline \multirow{3}{*}{$\begin{array}{l}\text { Sand } 50 \%+\text { Peat moss } \\
50 \%\end{array}$} & Fertilizer $0 \mathrm{~g}$ & 4.29 & 4.65 & 35.31 & 36.89 & 7.33 & 7.67 & 9.16 & 9.83 \\
\hline & Fertilizer $6 \mathrm{~g}$ & 4.45 & 4.77 & 38.72 & 40.23 & 8.04 & 8.36 & 12.66 & 13.16 \\
\hline & Fertilizer $12 \mathrm{~g}$ & 4.54 & 4.89 & 41.52 & 43.01 & 8.63 & 8.93 & 11.50 & 12.00 \\
\hline \multicolumn{2}{|l|}{ Mean } & 4.42 & 4.77 & 38.51 & 40.04 & 8.00 & 8.32 & 11.10 & 11.66 \\
\hline \multirow{3}{*}{$\begin{array}{l}\text { Sand } 25 \%+\text { Peat moss } \\
75 \%\end{array}$} & Fertilizer $0 \mathrm{~g}$ & 4.39 & 4.73 & 34.36 & 35.86 & 7.15 & 7.45 & 10.33 & 11.00 \\
\hline & Fertilizer $6 \mathrm{~g}$ & 4.55 & 4.97 & 36.28 & 37.77 & 7.54 & 7.85 & 12.83 & 13.50 \\
\hline & Fertilizer $12 \mathrm{~g}$ & 4.84 & 5.25 & 39.46 & 40.98 & 8.21 & 8.52 & 11.16 & 11.83 \\
\hline \multicolumn{2}{|l|}{ Mean } & 4.59 & 4.98 & 36.70 & 38.20 & 7.63 & 7.94 & 11.44 & 12.11 \\
\hline \multirow{3}{*}{ Mean (SRF) } & Fertilizer $0 \mathrm{~g}$ & 4.06 & 4.43 & 33.94 & 35.46 & 7.05 & 7.36 & 8.28 & 8.87 \\
\hline & Fertilizer $6 \mathrm{~g}$ & 4.20 & 4.57 & 36.48 & 37.99 & 7.57 & 7.89 & 10.66 & 11.20 \\
\hline & Fertilizer $12 \mathrm{~g}$ & 4.46 & 4.81 & 38.22 & 39.72 & 7.94 & 8.25 & 9.78 & 10.37 \\
\hline \multirow{3}{*}{ L.S.D. at 0.05} & DGM & 0.06 & 0.07 & 0.60 & 0.62 & 0.12 & 0.12 & 0.63 & 0.34 \\
\hline & SRF & 0.05 & 0.05 & 0.50 & 0.50 & 0.10 & 0.10 & 0.47 & 0.46 \\
\hline & DGM $\times \mathbf{S R F}$ & 0.35 & 0.11 & 1.02 & 1.03 & 0.23 & 0.18 & n.s & n.s \\
\hline
\end{tabular}


the bulbs was obtained by using 0.0 and $6.0 \mathrm{~g}$ SRF with a medium of $100 \%$ sand $(24.47$ and $24.66 \%$ ) in the first season.

\subsubsection{Nitrogen content in the leaves $(\%)$}

Nitrogen content in the leaves was significantly increased by increasing fertilization rates at $12.0 \mathrm{~g}$ in the two medium of $50 \%$ sand $+50 \%$ peat moss and $25 \%$ sand + $75 \%$ peat moss; (1.80 and $1.77 \%$ ) in the season of 2010. In the second season, the interaction between the two experiment factors was not significant.

\subsubsection{Phosphorus content in the leaves (\%)}

Using $6.0 \mathrm{~g}$ of SRF with $50 \%$ sand $+50 \%$ peat moss medium gave the highest phosphorus content in the leaves in the first and second one $(0.88 \%$ and $0.93 \%)$, respectively. The lowest percentage obtained of phosphorus content in the leaves was found using a combination of $100 \%$ sand medium and 6.0g SRF level in the first and second seasons (0.51\%and $0.57 \%)$, respectively.

\subsubsection{Potassium content in the leaves $(\%)$}

The data represented in Table (5) revealed that a significant increase in potassium content in the leaves was found by using a medium of $50 \%$ sand $+50 \%$ peat moss with 6.0 g SRF levels. It resulted in 3.89 and $4.14 \%$ ) potassium content in the leaves in the two seasons, respectively. Whereas, using 0.0 and $12.0 \mathrm{~g}$ SRF levels with a medium of $100 \%$ sand gave the lowest potassium content in the leaves in the first season (2.66 and $2.73 \%$, respectively). In the second season, this percentage was obtained with $100 \%$ sand medium with $12.0 \mathrm{~g}$ SRF level was $2.97 \%$.

\subsubsection{Nitrogen content in bulbs (\%)}

It was noted that increasing the fertilization rates at $12.0 \mathrm{~g}$ in combination of the two medium $50 \%$ sand $+50 \%$ peat moss and $25 \%$ sand $+75 \%$ peat moss gave the highest nitrogen content in the bulbs (1.41 and 1.39\%) in the first season, and (1.59 and 1.57\%) in the second season Table 5). The lowest nitrogen content in the bulbs observed was revealed by using sand alone and $0.0 \mathrm{~g}$ level of SRF ( 0.81 and $0.90 \%$ ) in the first and second seasons, respectively.

\subsubsection{Phosphorus content in the bulbs (\%)}

Application of $6.0 \mathrm{~g}$ SRF level in a medium of $50 \%$ sand $+50 \%$ peat moss gave the highest phosphorus content in the bulbs (0.91 and $0.96 \%$ ) in 2010 and 2011 seasons, respectively. However the lowest percentage of phosphorus content in the bulbs was obtained with sand medium when applied with 0.0 and $6.0 \mathrm{~g}$ SRF level $(0.56 \%$ and $0.57 \%)$ in the first season, whereas in the second one the lowest phosphorus content in the bulbs was obtained with $0.0 \mathrm{~g}$ SRF level and $100 \%$ sand medium treatment $(0.56 \%)$.

\subsubsection{Potassium content in the bulbs (\%)}

Potassium content in the bulbs increased significantly by using $6.0 \mathrm{~g}$ SRF level with a medium of $50 \%$ sand $+50 \%$ peat moss reaching 2.68 and $2.52 \%$ in the first and the second seasons, respectively. Whereas, the lowest percentage of potassium content in the bulbs was recorded in the combination of $100 \%$ sand medium with zero level of SRF level (1.88 and $1.72 \%$ ) in 2010 and 2011 seasons, respectively.

\section{DISCUSSION}

The results of this experiment showed an interaction between growing media and fertilization, where plant height was affected significantly by both experimental factors: growing media and fertilization on the vegetative growth of lilium plants.

Easter and Oriental lilies are heavy feeders, and low nutrition (especially $\mathrm{N}$ and $\mathrm{Ca}$ ) during forcing usually reduced plant quality (Miller, 1992). Using a media of $100 \%$ sand in combination with slow release fertilizer levels $(0.0,6.0$ and $12.0 \mathrm{~g})$ gave the shortest plant height.

Lilium plants accumulated more fresh weight with increasing SRF levels. These results matched with those found by Treder, (2008), noticed that the fresh weight of flower bud and leaves was affected by both growing media and fertilization. The higher $\mathrm{N}$ level $240 \mathrm{mg} \cdot \mathrm{dm}^{-3}$ in nutrient solution gave taller and heavier plants in both growing media sphagnum peat, bark and sand. The results obtained are in agreement with those reported by Treder (2005), who noticed that, intensively fertilized oriental lily plants were taller, had longer flower bud, higher fresh weight and larger dark green leaves.

Plant vegetative characters are influenced by many factors; genetic information, environmental factors and nutritional supplies. Thus, the variation in plant vegetative characters in the present study was due to the various level of fertilization used. It is obvious that increasing the fertilization rate from $0.0 \mathrm{~g}$ SRF to $12.0 \mathrm{~g}$ per plant SRF caused a highly that increasing the fertilization rate from $0.0 \mathrm{~g}$ SRF to $12.0 \mathrm{~g}$ per plant SRF caused a highly significant increase in 
Table (5): Means of chemical composition of Lilium hybrida cv. Golden Tycoon plants as influenced by different growing media (DGM), slow release fertilizer (SRF) and their combinations (DGM $\times$ SRF) in the two seasons of 2010 and 2011.

\begin{tabular}{|c|c|c|c|c|c|c|c|c|c|c|c|c|c|c|c|c|c|}
\hline \multirow[t]{2}{*}{ Media } & \multirow[t]{2}{*}{$\begin{array}{c}\text { SRF } \\
\text { fertilizers }\end{array}$} & \multicolumn{2}{|c|}{$\begin{array}{c}\text { Total } \\
\text { chlorophyll } \\
\text { content in } \\
\text { leaves }(\mathrm{mg} / \mathrm{g})\end{array}$} & \multicolumn{2}{|c|}{$\begin{array}{c}\text { Total } \\
\text { carbohydrates } \\
\text { content in } \\
\text { bulbs }(\%)\end{array}$} & \multicolumn{2}{|c|}{$\begin{array}{c}\text { Nitrogen } \\
\text { content in } \\
\text { leaves }(\%)\end{array}$} & \multicolumn{2}{|c|}{$\begin{array}{l}\text { Phosphorus } \\
\text { content in } \\
\text { leaves }(\%)\end{array}$} & \multicolumn{2}{|c|}{$\begin{array}{l}\text { Potassium } \\
\text { content in } \\
\text { leaves }(\%)\end{array}$} & \multicolumn{2}{|c|}{$\begin{array}{l}\text { Nitrogen } \\
\text { content in } \\
\text { bulb }(\%)\end{array}$} & \multicolumn{2}{|c|}{$\begin{array}{c}\text { Phosphorus } \\
\text { content in } \\
\text { bulb (\%) }\end{array}$} & \multicolumn{2}{|c|}{$\begin{array}{l}\text { Potassium } \\
\text { content in } \\
\text { bulb }(\%)\end{array}$} \\
\hline & & 2010 & 2011 & 2010 & 2011 & 2010 & 2011 & 2010 & 2011 & 2010 & 2011 & 2010 & 2011 & 2010 & 2011 & 2010 & 2011 \\
\hline \multirow{3}{*}{$\begin{array}{l}\text { Sand } \\
100 \%\end{array}$} & $\begin{array}{l}\text { Fertilizer } \\
\text { 0 g }\end{array}$ & 0.928 & 0.932 & 24.47 & 25.64 & 1.02 & 1.05 & 0.51 & 0.57 & 2.66 & 2.90 & 0.81 & 0.90 & 0.56 & 0.56 & 1.88 & 1.72 \\
\hline & $\begin{array}{l}\text { Fertilizer } \\
6 \mathrm{~g}\end{array}$ & 0.992 & 0.997 & 24.66 & 25.52 & 1.24 & 1.28 & 0.54 & 0.59 & 2.85 & 3.10 & 0.98 & 1.09 & 0.57 & 0.58 & 2.01 & 1.85 \\
\hline & $\begin{array}{l}\text { Fertilizer } \\
12 \mathrm{~g}\end{array}$ & 0.967 & 0.971 & 27.58 & 28.57 & 1.32 & 1.34 & 0.61 & 0.66 & 2.73 & 2.97 & 1.03 & 1.16 & 0.65 & 0.66 & 1.93 & 1.77 \\
\hline \multicolumn{2}{|l|}{ Mean } & 0.962 & 0.966 & 25.57 & 26.57 & 1.19 & 1.22 & 0.55 & 0.60 & 2.74 & 2.99 & 0.94 & 1.05 & 0.59 & 0.60 & 1.94 & 1.78 \\
\hline \multirow{3}{*}{$\begin{array}{l}\text { Sand } \\
75 \%+\text { Peat } \\
\text { moss } 25 \%\end{array}$} & $\begin{array}{l}\text { Fertilizer } \\
0 \mathrm{~g}\end{array}$ & 0.918 & 0.922 & 29.16 & 30.34 & 1.14 & 1.18 & 0.62 & 0.67 & 3.04 & 3.29 & 0.90 & 1.01 & 0.65 & 0.67 & 2.13 & 1.97 \\
\hline & $\begin{array}{l}\text { Fertilizer } \\
6 \mathrm{~g}\end{array}$ & 1.199 & 1.203 & 33.12 & 34.15 & 1.42 & 1.46 & 0.67 & 0.72 & 3.58 & 3.83 & 1.12 & 1.26 & 0.71 & 0.73 & 2.49 & 2.32 \\
\hline & $\begin{array}{l}\text { Fertilizer } \\
12 \mathrm{~g}\end{array}$ & 1.173 & 1.177 & 36.66 & 37.52 & 1.47 & 1.50 & 0.70 & 0.75 & 3.67 & 3.92 & 1.15 & 1.30 & 0.73 & 0.76 & 2.54 & 2.38 \\
\hline \multicolumn{2}{|l|}{ Mean } & 1.096 & 1.100 & 32.98 & 34.00 & 1.34 & 1.38 & 0.66 & 0.71 & $\mathbf{3 . 4 3}$ & 3.68 & 1.056 & 1.19 & 0.69 & 0.72 & 2.38 & 2.22 \\
\hline \multirow{3}{*}{$\begin{array}{l}\text { Sand } \\
\mathbf{5 0 \% + P e a t} \\
\text { moss } 50 \%\end{array}$} & $\begin{array}{l}\text { Fertilizer } \\
0 \mathrm{~g}\end{array}$ & 1.009 & 1.013 & 31.78 & 32.69 & 1.55 & 1.58 & 0.75 & 0.80 & 3.60 & 3.84 & 1.21 & 1.36 & 0.79 & 0.82 & 2.49 & 2.33 \\
\hline & $\begin{array}{l}\text { Fertilizer } \\
6 \mathrm{~g}\end{array}$ & 1.316 & 1.320 & 35.13 & 36.10 & 1.77 & 1.81 & 0.88 & 0.93 & 3.89 & 4.14 & 1.39 & 1.56 & 0.91 & 0.96 & 2.68 & 2.52 \\
\hline & $\begin{array}{l}\text { Fertilizer } \\
12 \mathrm{~g}\end{array}$ & 1.256 & 1.260 & 39.27 & 40.14 & 1.80 & 1.83 & 0.81 & 0.85 & 3.79 & 4.03 & 1.41 & 1.59 & 0.84 & 0.88 & 2.62 & 2.45 \\
\hline \multicolumn{2}{|l|}{ Mean } & 1.193 & 1.197 & 35.39 & 36.31 & 1.70 & 1.74 & 0.81 & 0.86 & 3.76 & 4.00 & 1.33 & 1.50 & 0.84 & 0.88 & 2.59 & 2.43 \\
\hline \multirow{3}{*}{$\begin{array}{l}\text { Sand } \\
25 \%+\text { Peat } \\
\text { moss } 75 \%\end{array}$} & $\begin{array}{l}\text { Fertilizer } \\
0 \mathrm{~g}\end{array}$ & 1.046 & 1.051 & 34.43 & 35.24 & 1.61 & 1.64 & 0.63 & 0.68 & 3.58 & 3.82 & 1.26 & 1.43 & 0.66 & 0.68 & 2.48 & 2.32 \\
\hline & $\begin{array}{l}\text { Fertilizer } \\
6 \mathrm{~g}\end{array}$ & 1.308 & 1.312 & 35.93 & 36.59 & 1.80 & 1.83 & 0.73 & 0.78 & 3.64 & 3.89 & 1.41 & 1.59 & 0.76 & 0.79 & 2.52 & 2.36 \\
\hline & $\begin{array}{l}\text { Fertilizer } \\
12 \mathrm{~g}\end{array}$ & 1.258 & 1.262 & 39.27 & 40.12 & 1.77 & 1.81 & 0.69 & 0.74 & 3.70 & 3.95 & 1.39 & 1.57 & 0.72 & 0.75 & 2.56 & 2.40 \\
\hline \multicolumn{2}{|l|}{ Mean } & 1.204 & 1.208 & 36.54 & $\mathbf{3 7 . 3 1}$ & 1.72 & 1.76 & 0.68 & 0.73 & 3.64 & 3.88 & 1.35 & 1.53 & 0.71 & 0.74 & 2.52 & 2.36 \\
\hline \multirow{3}{*}{$\begin{array}{l}\text { Mean } \\
\text { (SRF) }\end{array}$} & $\begin{array}{l}\text { Fertilizer } \\
0 \mathrm{~g}\end{array}$ & 0.975 & 0.979 & 29.96 & 30.97 & 1.33 & 1.36 & 0.62 & 0.68 & 3.22 & 3.46 & 1.04 & 1.17 & 0.66 & 0.68 & 2.24 & 2.08 \\
\hline & $\begin{array}{l}\text { Fertilizer } \\
6 \mathrm{~g}\end{array}$ & 1.203 & 1.208 & 32.21 & 33.09 & 1.55 & 1.59 & 0.70 & 0.75 & 3.49 & 3.74 & 1.22 & 1.37 & 0.73 & 0.76 & 2.42 & 2.26 \\
\hline & $\begin{array}{l}\text { Fertilizer } \\
12 \mathrm{~g}\end{array}$ & 1.163 & 1.167 & 35.69 & 36.58 & 1.59 & 1.62 & 0.70 & 0.75 & 3.47 & 3.71 & 1.24 & 1.40 & 0.73 & 0.76 & 2.41 & 2.25 \\
\hline \multirow{3}{*}{$\begin{array}{l}\text { L.S.D. at } \\
0.05\end{array}$} & DGM & 0.01 & 0.01 & 1.33 & 1.51 & 0.03 & 0.05 & 0.01 & 0.02 & 0.02 & 0.03 & 0.01 & 0.03 & 0.02 & 0.01 & 0.05 & 0.03 \\
\hline & SRF & 0.01 & 0.01 & 0.74 & 1.13 & 0.02 & 0.04 & 0.01 & 0.01 & 0.04 & 0.09 & 0.01 & 0.01 & 0.01 & 0.01 & 0.06 & 0.03 \\
\hline & $\begin{array}{l}\text { DGM } \\
\times \text { SRF }\end{array}$ & 0.02 & 0.02 & 1.80 & n.s & 0.05 & n.s & 0.01 & 0.08 & 0.08 & 0.15 & 0.05 & 0.04 & 0.03 & 0.02 & 0.11 & 0.06 \\
\hline
\end{tabular}


many vegetative growth characters such as plant height, leaf fresh and dry weights, leaf area and the number of leaves per plant. These results are in agreement with those reported on Dhalia flowers (Adnan et al., 2005). They recommended that, NPK elements applied to the plants found to be synergetic to one another and they should be in favor for good vegetative growth. These results also agree with those reported Jagadeeswaran et al., 2005 on Curcuma longa. They recorded that NPK (SRF) significantly enhanced agronomic efficiency, apparent recovery and partial factor productivity.

Also, these results agree with those on lilium (Barnes et al., 2011). They recorded that lilium plants grown under nitrogen deficient conditions gave $40 \%$ less in dry weight than the control plant.

Using the soil medium $(50 \%$ sand $+50 \%$ peat moss) in combination with high SRF levels significantly enhanced growth parameters of lilium in this study. These results are in agreement with those reported by Kiran et al., (2007) on Dhalia pinnata, where plants grown in media of sand+silt+leaf mold were proved to be superior in all growth and developmental parameters such as plant height, stem thickness, number of branches per plant, number of flowers per plant, number of petals per flower, diameter and vase life of the flower.

The same trend of results were observed by Seyedi et al., (2012) on lilium, where increasing the percentage of cocco peat substrates in the media caused an increase in all growth indices particularly plant height, stem diameter, flower diameter and bud number. The results are in agreement with Younis et al., 2010) where using sand +silt +leaf compost +spent compost) (1:1:1:1) on croton plants was considered best medium in pot plant production. The same on gerbera by Khalaj et al., (2011) who noted that perlite +peat +clay mix $(25 \%+70 \%+5 \%)$ produced significantly the maximum number of flowers and other quality characteristics.

Growth and flowering of lilium plants were greatly affected with high levels of SRF and soil medium treatments. By the same way lilium bulb production was highly affected by the two experimental factors whereas high levels of SRF $12.0 \mathrm{~g}$ and using a medium of $50 \%$ sand $+50 \%$ peat moss gave a great effect on bulb fresh and dry weights. It had also a great effect on flower production represented in flower fresh and dry weights, flower diameter, stalk diameter, stem fresh and dry weights. These results are in agreement with those reported Miller, (1992) and Treder (2005). In these studies using these two successful treatments led to an increase in the total carbohydrate content in bulbs, N, P and K content in leaves and $\mathrm{N}, \mathrm{P}$ and $\mathrm{K}$ in bulbs. It also greatly affected the total chlorophyll in leaves.

Thus, using of slow-release fertilizer may be an effective management practice to improve growth performance under suitable soil mixture conditions. Poor growth of lilies grown without fertilization corresponds to previous results on oriental lily obtained by (Treder, 2000).

Nutrient recovery from applied SRF and soil mixture treatment is primally important for lilium being a long vegetation growing crop. The physical and chemical properties of soil, texture, structure and organic matter as well as N, P and K contents are dominant factors affecting lilium production flowers and bulbs.

Finally, concerning the interaction between the two experimental factors, using the high level of SRF $12.0 \mathrm{~g}$ and the media of $50 \%$ sand $+50 \%$ peat moss, greatly affected the production of lilium flowering and bulbs.

\section{REFERENCES}

Adnan Y., Aslam M. P. and Atif R. (2005). Effect of different levels of nitrogen, phosphorus and potash fertilizers on growth of Dohlia coccinea cv. Decorative. Caderno de Pesquisa, serie Biologia.18(3): 8-13.

Allen O. M. (1959). Experimental in soil Bacteriology. Burgess Publishing Co. Minneapolis USA. pp. $83-85$.

Barnes J., Whipker B. E. and McCall I.( 2011). Characterization of nutrient disorders of Lilium grandiflorum ' Nellie While' and Lilium hybrida ' Brunello'. Acta Hort. Proc. $11^{\text {th }}$ on the genus Lilium, 205-211.

Beattie D.J. and White J.W. (1993). Lilium hybrids and species. p.423-454. In: A.A. De Hertogh and M. Le Nard (eds.), The Physiology of Flower Bulbs, Elsevier, Amsterdam.

Champman H. D. and Pratt P.F. (1961). Method of Analysis of Soil, Plants and Water. Univ. of California p.61.

Darwish M. A. and Sakr W. R.( 2008). Effect of commercial fertilizers and gibberellic acid on growth and chemical composition of Hedera canarieinsis, Wild plants. J. Product and Dev., 13: 489-505.

De Hertogh A.A. (1989). Holland Bulb Forcers' Guide. $4^{\text {th }}$ ed., Int. Flower Bulb Center, 
Hillegom, The Netherlands. 369 p.

Dubios M., Gilles K., Hamlton J., Rebers P. and Smith, F. (1956). Colourimetric method for determination of sugars and related substances. Analyt. Chem. 28(3): 350- 356.

Erwin J.E. (1998). Easter lily production. Minn. Comm. Flower Grow. Bull., 47(5):1-10.

Hussein M.M.M. (2002). Growth of Cryptostegia grandiflora, R.Br. in sandy soil as affected by fertilization and soil amendments. Proc. of the $2^{\text {nd }}$ Cong. on Recent Tech. in Agric., Fac. Agric., Cairo Univ., 28-30 October, 2002. Bull. Fac. Agric., Cairo Univ., Egypt, Special edition: pp: 362-378.

Jackson M. L. (1962). Soil Chemical Analysis. Prentice Hall Inc. Englwood, Cliffs, NJ. USA.

Jagadeeswaran R., Murugappan V. and Govin daswamy M. ( 2005). Effect of slow release NPK fertilizer sources on the nutrient use efficiency in Tumeric (Curcuma longa L.). World J. Agric. Sci., L (1):65-69.

Khalaj M. A., Amiri M. and Sindhu S. S. (2011). Study on the effect of different growing media on the growth and yield of gerbera (Gerbera jamesonii L.). J. of Ornam. and Hort. Plants, 1 (3): 185-189.

Kiran M., Baloch J., Waseem K., Saleem M., Khan J. and Khan M. (2007). Effect of different growing media on the growth development of Dahlia (Dahlia pinnata) under the agro-climatic conditions of Dera Ismail Khan. Pak. J. Biol. Sci., 10 (22): 4140-4143.

Miller W. B. (1992). Easter and hybrid lily production. Timber Pres, Inc. Portland Oregon, UAS.

Moran R. and Porath D. (1980). Chlorophyll Determination in Intact Tissues Using N,NDimethylformamide. Department of Botany, The Geovge. S. Wise faculty for life sciences, Tel Aviv University, Ramat
Aviv, Israel Plant Physiol., 65: 478- 479.

Seyedi N., Torkashvand M. A. and Allahyaei M. S. (2012). The impact of perlate and coccopeat as the growth media on lilium. Asian J. Exp. Biol. Sci., 3 (3): 502-505.

Snedecor G. and Cochran W. (1974). Statistical Methods. Sixth Edition. Iowa State University Press. Ames. Iowa. USA.

Sonneveld C., Baas H.M., Nijssen H.M.C. and de Hoog J. (1999). Salt tolerance of flower crops grown in soilless culture. J. Plant Nutr 22 (6): 1033-1048.

Treder J. (2000). Influence of fertilization on growth, flowering and mineral nutrient content of oriental lilies. Zesz, NAUK. INST. SADOWN. KWIAC. 7:375-380. (in polish with English abstract).

Treder J. (2001). The effect of light and nutrition on growth and flowering of oriental lilies. Acta Hort., 54: 523-528.

Treder J. (2003). Effects of supplementary lighting on flowering, plant quality and nutrient requirements of lily 'Laura Lee' during winter forcing. Scientia Hort., 98: 37-47.

Treder J. (2005). Growth and quality of oriental lilies at different fertilization levels. Acta Hort., 673: 297-302.

Treder J. (2008). The effects of coco peat and fertilization on the growth and flowering of oriental lily 'Star Gazer'. Journal of Fruit and Ornamental Plant Research. Vol.16:361-370.

Volterrani M., Gaetani M., Grossi N., Pardini G., Miele S. and Magni S. (1999). The use of organic fertilizers on turf. Dynamics of nitrogen uptake and losses Rivista di Agronomia, 33: 34-39.

Younis A., Riaz A. M., Wasseem M., Khan A. and Nadeem M. (2010). Production of quality croton (Codiaeum variegatum) plants by using different growing media. Amer-Euras. J. Agric. \& Envir on Sci., 7 (2): 232-237. 


\section{تأثير مستويات مختلفة من الأسمدة بطيئة التحلل على إنتاج نباتات الليليم النامية فى بيئات مختلفة *نادر الثنهورى -رحاب صفار}

قسم بحوث الحدائق النباتية بأنطو نيادس - * قسم بحوث نباتات الزينة بأنطونيادس - معهر بحوث البساتين

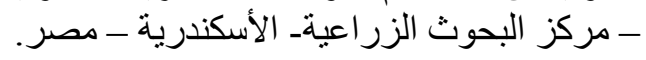

\section{ملخص}

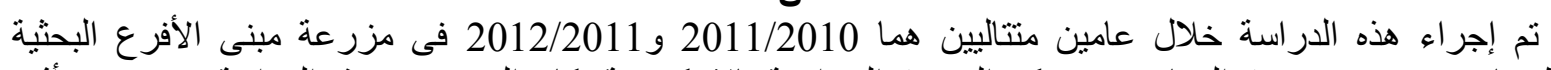

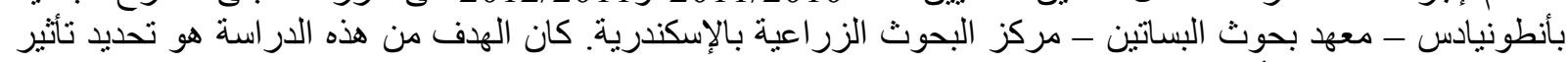

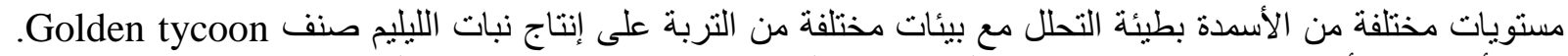

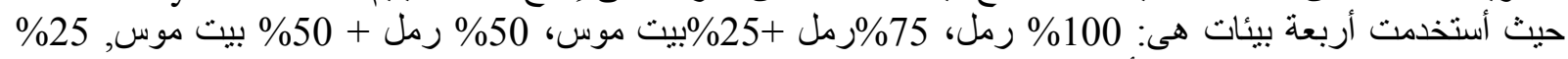

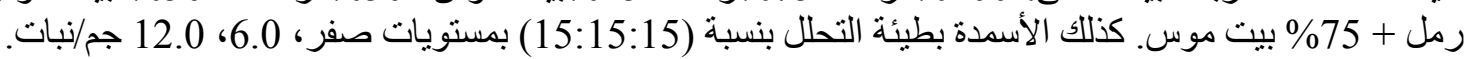

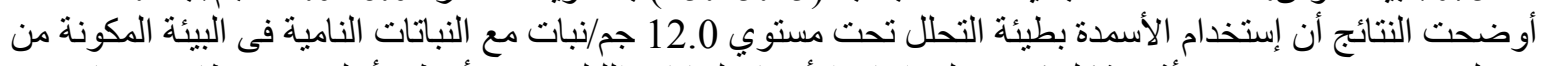

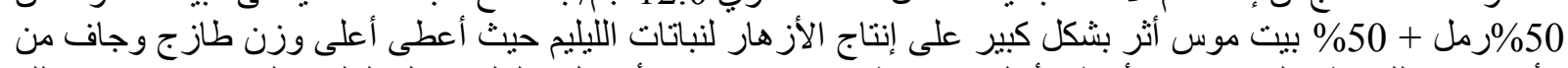

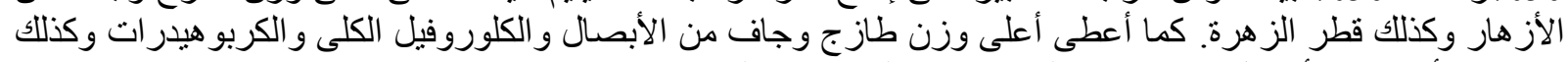

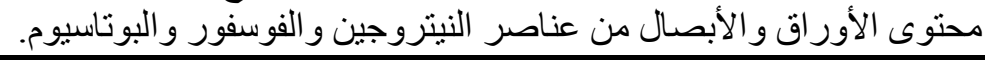

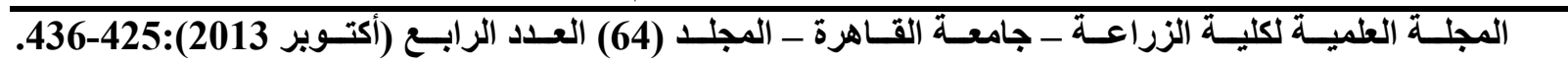

